\title{
Possibility of GPS precipitable water vapour for reservoir inflow forecasting
}

\section{Prawit UANG-AREE ${ }^{1) A B C D E F}$, Sununtha KINGPAIBOON ${ }^{2) A E} \bowtie$}

\author{
1) Sakon Nakhon Rajabhat University, Faculty of Science and Technology, Sakon Nakhon, Thailand; \\ e-mail: prawit@snru.ac.th \\ 2) Khon Kaen University, Department of Agricultural Engineering, Agricultural Machinery and Postharvest Technology Cen- \\ ter, 123 Mitraphab Road, Nai-Muang, Muang District, 40002 Khon Kaen, Thailand; e-mail: sununtha@kku.ac.th
}

For citation: Uang-aree P., Kingpaiboon S. 2018. Possibility of GPS precipitable water vapour for reservoir inflow forecasting. Journal of Water and Land Development. No. 36 p. 161-171. DOI: 10.2478/jwld-2018-0016.

\begin{abstract}
We investigated the possibility of using GPS precipitable water vapour (GPS-PWV) for forecasting reservoir inflow. The correlations between monthly GPS-PWV and the inflow of two reservoirs were examined and the relationship tested, using a group method of data handling (GMDH) type neural network algorithm. The daily and monthly reservoir inflows were directly proportional to daily and monthly GPS-PWV trends. Peak reservoir inflow, however, shifted from the peak averages for GPS-PWV. A strong relationship between GPS-PWV and inflow was confirmed by high $R^{2}$ values, high coefficients of correlation, and acceptable mean absolute errors $(M A E)$ of both the daily and monthly models. The Ubon Ratana reservoir model had a monthly $M A E$ of $54.19 \cdot 10^{6} \mathrm{~m}^{3}$ and a daily $M A E$ of $5.40 \cdot 10^{6} \mathrm{~m}^{3}$. By comparison, the Lumpow reservoir model had a monthly $M A E$ of $25.65 \cdot 10^{6} \mathrm{~m}^{3}$ and a daily $M A E$ of $2.62 \cdot 10^{6} \mathrm{~m}^{3}$. The models using GPS-PWV as input data responded to extreme inflow better than traditional variables such that reservoir inflow could be predicted using GPS-PWV without using actual inflow and rainfall data. GPS-PWV, thus, represents a helpful tool for regional and national water management. Further research including more reservoirs is needed to confirm this preliminary finding.
\end{abstract}

Key words: $G M D H$, hydrology, $P W V$, water management, watershed

\section{INTRODUCTION}

Water is an essential component of life, generally delivered through the hydrologic cycle. Dramatic worldwide population growth has amplified the importance of water usage for human consumption, power generation, and agriculture. Notwithstanding human ingenuity, we cannot control the amount or distribution of rainfall - evidently disrupted by the cumulative effects of human activity - so there can be too little or too much at the wrong time resulting in either drought or flooding.

Water resource management (WRM) is a major tool used for regulating water levels and usage, and planning seasonal water consumption. To achieve adequate WRM involves two essential factors: workable forecasting models, and authentic data. Reservoir inflow forecasting is a major tool for reservoir management, since it can help with flood prevention and hydropower optimization. Several hydrological and hydraulic models have been developed or used in the last decade such as MIKE11 [DHI 2004; PATRO et al. 2009], MGB-IPH [COLLISCHONN et al. 2007], SWAT [NOOR et al. 2014], SWAT-MODFLOW [BAILEY et al. 2016], HEC-HMS model [SKHAKHFA, OUERDACHI 2016]; however, the accuracy of these models depends upon the precision of data measurement. The models need adequate and varied input data on precipitation, potential evapotranspiration, temperature, and flow volume [NAYAK et al. 2013]; consequently, any model will be complex and multifactorial. 
Other methods of inflow forecasting have been developed to deal with this complexity. For example, the hydrologic time series model uses an auto-regressive moving average (ARMA) or auto-regressive integrated moving average (ARIMA) for forecasting [VALIPOUR et al. 2013; WANG et al. 2015]. Various approaches to advanced modeling have helped to predict inflow; e.g., artificial neural network [ABDELLATIF et al. 2015; COULIBALY et al. 2000; TAGHI SATTARI et al. 2012; ZEALAND et al. 1999], multilinear regression [MAGAR, JOTHIPRAKASH 2011], auto-regressive artificial neural networking [VALIPOUR et al. 2012], dynamic linear modelling [LIMA et al. 2014], Thomas-Fiering modelling, wavelet neural networking [CUI et al. 2016], and hybrid modelling [BAI et al. 2016]. Notwithstanding the rigour of these methods, these methods frequently disregard extreme inflow events, and for best results the input variables for numerical models require actual, measured hydrologic parameters (i.e., precipitation and inflow volume).

Precipitable water vapour (PWV) represents the amount of water vapour across a column of the troposphere: a valuable parameter for numerical weather prediction (NWP) [CHEN, LIU 2014] as well as an essential component of weather monitoring [KULESHOV et al. 2016; LIANG et al. 2015; TSUDA et al. 2013]. PWV is measured using radiosonde data or PWV can be estimated using satellite data [DEETER 2007]. It can be computed using NWP [CHEN, LIU 2014] and/or atmospheric microwave radiometer (AMR) [JI et al. 2017]. It is also possible that specific humidity, relative humidity, and water vapour pressure from surface meteorology stations can be used to estimate PWV, albeit large errors can be expected [MAGHRABI, AL DAJANI 2013; UANG-AREE et al. 2014].

An alternative method is to estimate PWV using GPS data. The method relies on the propagation delay of a dual-frequency microwave signal (band L1 at 1574.42 $\mathrm{MHz}$ and L2 at 1227.60 $\mathrm{MHz}$ ) sent between GPS satellites and ground stations [BEVIS et al. 1994]. The GPS-PWV delivers an accuracy comparable to an atmospheric microwave radiometer [CHEN, LIU 2014; SOHN et al. 2012], ERA-Interim data [BORDI et al. 2016; NAMAOUI et al. 2017] and Very Long Baseline Interferometry (VLBI) [CHOY et al. 2015].

The PWV estimated using data from a ground-based GPS is capable of revealing the amount of atmospheric moisture for several kilometers; furthermore, it has been used in various meteohydrological studies such as of drought [BORDI et al. 2014; 2016], the southwest monsoon
[UANG-AREE et al. 2015], El Niño [LlLAMEDO et al. 2017; SUPARTA, ISKANDAR 2012], rainfall [YEH et al. 2016], and flooding [SUPARTA et al. 2012; SUPARTA, RAHMAN 2016]. The GPS derived zenith total delay (ZTD), which is a percentage of the GPS-PWV has also been used to study storms [AKILAN et al. 2015].

A case study was designed to test the possibility of a new variable for reservoir inflow forecasting, and predicting extreme, sudden inflows. The GPS-PWV has been widely used in meteo-hydrological studies and the model responded well with respect to extreme events. The method has not, however, been used for reservoir inflow forecasting; so, we sought to test it for reservoir inflow forecasting. We planned to determine the correlation between GPS-PWV and inflows, and to test the possibility of GPS-PWV as an input for reservoir inflow forecasting using the group method of data handling (GMDH).

\section{MATERIAL AND METHODS}

\section{STUDY AREA AND DATA USE}

The study area is a plateau in northeastern Thailand; also known as the Khorat Plateau. The average altitude is $200 \mathrm{~m}$ above sea level, and it inclines towards the east. This plateau comprises two basins (i.e., the Mun and the Chi); both of are subbasins of the Mekong basin. Seasonal depressions and the southwest monsoon (between mid-May and early October) are the major contributors to streamflow. We sought to determine the correlation between GPSPWV and inflows of the two largest reservoirs in this area (i.e., the Ubon Ratana and Lumpow reservoirs). Both reservoirs are located in the geographic middle of the Chi basin (Fig. 1).

The Ubon Ratana reservoir is located at latitude $16.77^{\circ} \mathrm{N}$ and longitude $102.62^{\circ} \mathrm{E}$. It has a capacity of $2,431 \cdot 10^{6} \mathrm{~m}^{3}$. Inflows to Ubon Ratana come from

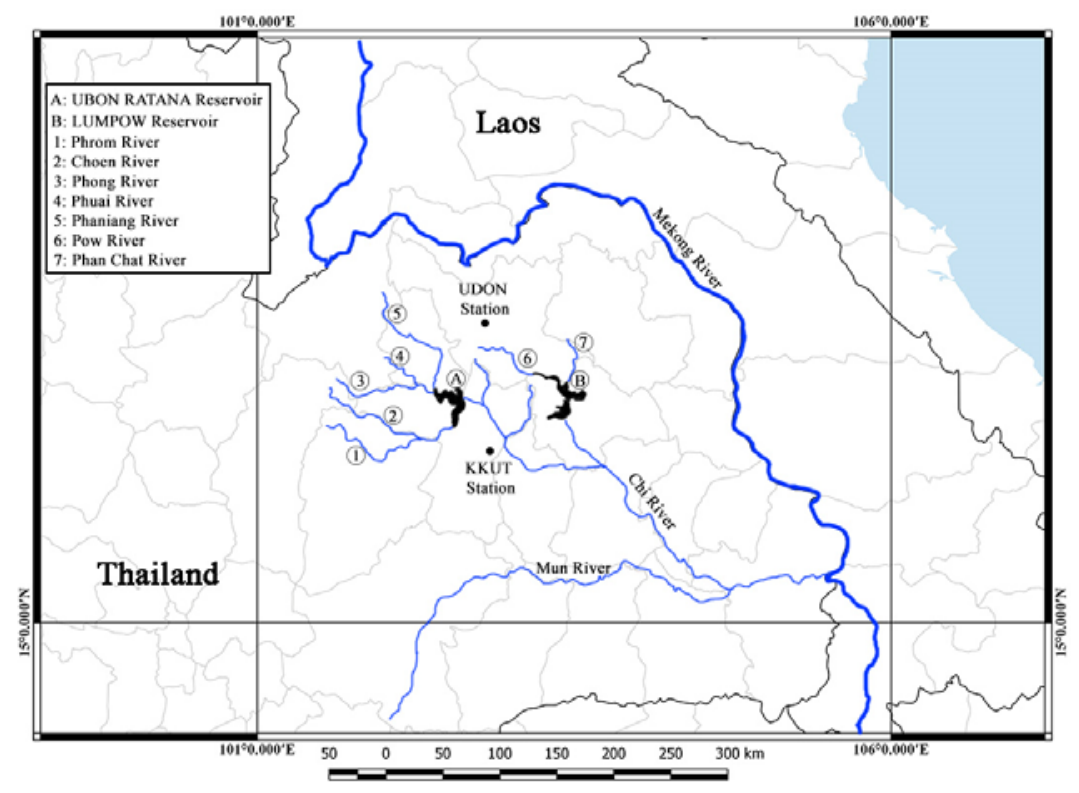

Fig. 1. Study area; source: own elaboration 
5 minor basins from the geographic middle of the Chi basin (namely, the Phrom, Choen, Phong, Phuai and Phaniang basins), with an annual average inflow of $2,492 \cdot 10^{6} \mathrm{~m}^{3}$.

The Lumpow reservoir is located at latitude $16.60^{\circ} \mathrm{N}$ and longitude $103.44^{\circ} \mathrm{E}$. It has a capacity of $1,980 \cdot 10^{6} \mathrm{~m}^{3}$. Inflows to the Lumpow reservoir come from 2 minor basins in the geographic middle of the Chi basin (viz., the Pow and Phan Chat basins), with an annual average inflow of $2,258 \cdot 10^{6} \mathrm{~m}^{3}$. Both reservoirs only receive inflows from monsoons and seasonal depressions.

Data on the daily and monthly reservoir inflows between 2010 and 2014 were documented by the Royal Irrigation Department of Thailand. The daily and monthly average precipitable water vapour (PWV) were estimated using two ground-based GPS recording units in Khon Kaen and Udon Thani. The GPS data from the Khon Kaen station (KKUT) (located at latitude $16.47^{\circ} \mathrm{N}$ and longitude $102.83^{\circ} \mathrm{E}$ ) and the Udon Thani station (UDON) (located at latitude $17.41^{\circ} \mathrm{N}$ and longitude $102.78^{\circ} \mathrm{E}$ ) were recorded using a GPS receiver (Trimble 4000SSi and Leica GRX1200 Pro, respectively). The GPS data were converted into RINEX, which was then used to create data files for GPS-PWV estimation.

\section{GPS-PWV ESTIMATION}

The GPS-PWVs were estimated using a rationalisation of the zenith wet delay $(Z W D)$ against a dimensionless constant of proportionality:

$$
P W V=\Pi \cdot Z W D
$$

Where: $Z W D=$ the zenith wet delay (i.e., the length of the GPS signal transmission delay through water in the atmosphere measured in mm) [BEVIS et al. 1994]; $\Pi=$ a dimensionless constant of proportionality defined as per ASKNE and NORDIUS [1987]:

$$
\Pi=\frac{10^{6}}{R_{v}\left(k_{2}^{\prime}+\frac{k_{3}}{T_{m}}\right)}
$$

Where: $R_{v}=$ the specific gas constant of water vapour; $k_{2}^{\prime}$ and $k_{3}=$ the refractivity constants; $T_{m}=$ the weighted mean temperature of the atmosphere in which $T_{m}=70.2+0.72 T_{s} ; T_{s}=$ the surface temperature $\left({ }^{\circ} \mathrm{C}\right)$ [DAVIS et al. 1985].

The $Z W D$ s were estimated using the difference in zenith total delays (ZTDs) and zenith hydrostatic delays (ZHDs); thus:

$$
Z W D=Z T D-Z H D
$$

Where: $Z T D=$ the zenith total delay (i.e., the length of GPS signal transmission delay through the atmosphere measured in $\mathrm{mm}$ ); $Z H D$ the zenith hydrostatic delay (i.e., the length of GPS signal transmission delay through gases in the atmosphere measured in $\mathrm{mm}$ ) [DAVIS et al. 1985].
$Z H D$ can be estimated using the relationship between atmospheric pressure and a function of location, which can be defined as per ELGERED et al. [1991]:

$$
Z H D=(2.2779 \pm 0.0024) \frac{P}{f(\lambda, H)}
$$

Where: $P=$ the surface atmospheric pressure $(\mathrm{hPa})$; $f(\lambda, H)=$ the function of location given by:

$$
f(\lambda, H)=(1-0.00266 \cos 2 \lambda-0.00028 H)
$$

Where: $\lambda=$ the latitude of the GPS ground base station; $H=$ the ellipsoid height of the ground station $(\mathrm{km})$.

ZTD can be evaluated using GAMIT (the postprocessing GPS data software on UNIX base), which uses the difference between the true propagation path and the assumed straight-line of GPS-signal (see HERRING et al. [2015], for details).

\section{MODEL FITTING AND VALIDATION}

The daily and monthly GPS-PWV of the two chosen GPS ground-based stations and the inflows of both reservoirs (between April 2010 and May 2014) were standardised, and any resemblances compared. In addition, a correlation analysis was performed using IBM SPSS Statistics software and the polynomial neural network (PNN) implemented-also known as the group method of data handling (GMDH). IVAKHNENKO [1971] provided the input variables needed to regress the mathematical relationships. GMDH is a data mining computational method; it can be used to create a relatively accurate mathematical model without defining the relationship between the variables. The basic connection between inputs and an output can be expressed as:

$$
y=a_{0}+\sum_{i=1}^{n} a_{i} f_{i}
$$

Where: $a=$ the coefficients; $n=$ the number of base functions; $f=$ the base function.

The well-known base function of GMDH is the Kolmogorov-Gabor polynomial:

$$
\begin{aligned}
& y=a_{0}+\sum_{i=1}^{m} a_{i} x_{i}+\sum_{i=1}^{m} \sum_{j=1}^{m} a_{i j} x_{i} x_{j}+ \\
& +\sum_{i=1}^{m} \sum_{j=1}^{m} \sum_{k=1}^{m} a_{i j k} x_{i} x_{j} x_{k}
\end{aligned}
$$

Where: the various $x=$ the input variables; $m=$ the number of variables.

GMDH hereby "selects" the various algorithms (i.e., combinatorial (COMBI), multilayer algorithm, harmonic, and fuzzy). GMDH can, moreover, be used in neural networks (Fig. 2). The GMDH-type neural network is a popular and comparatively accurate regression algorithm [EBTEHAJ et al. 2015]. Thus, we can choose the GMDH-type neural network with 3 hidden layers as the main algorithm for testing the possibility that GPS-PWV can forecast reservoir inflow. The GPS-PWV will be analysed to confirm their correlation, and the input data will be separated into 


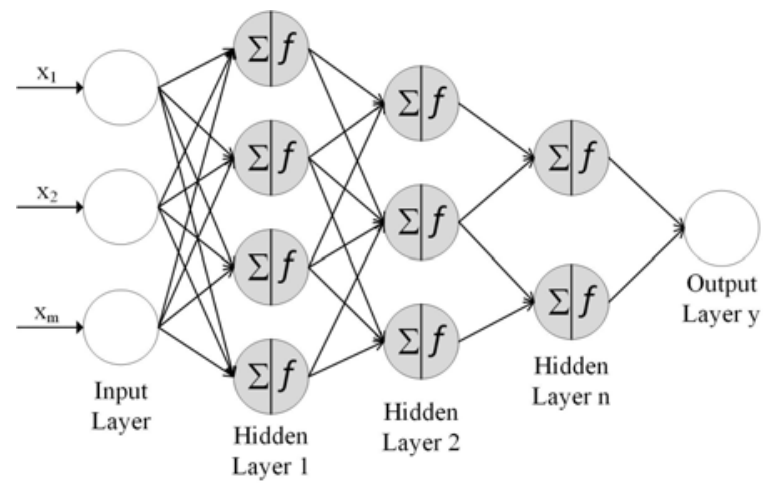

Fig. 2. GMDH-type neural network; $x_{1}, x_{2}, x_{m}=$ the input variables, $f=$ the base function, $\mathrm{GMDH}=$ group method of data handing; source: own elaboration

2 groups: 1) $70 \%$ for the model fit data, and 2) $30 \%$ for the validation data; the achievement data-splitting that use to forecast inflow is the 70/30 ratio [JOTHIPRAKASH, KOTE 2011]. The model fit data will be analysed to forecast reservoir inflow using the GMDH-type neural network technique. Finally, the validation data will be analysed to assess the model.

\section{RESULTS AND DISCUSSION}

\section{VARIABILITY OF GPS-PWV}

As long as the estimation of GPS-PWV for the average monthly GPS-PWV of the two chosen stations was between 20.92 and $63.47 \mathrm{~mm}$, the overall average would be $48.39 \mathrm{~mm}$. The average daily GPS-PWV of both stations was between 12.42 and 67.89 $\mathrm{mm}$. The average GPS-PWV at KKUT was $48.93 \mathrm{~mm}$ and at UDON $48.41 \mathrm{~mm}$. They had smaller values during the dry season (November-April), and trended to have higher ones during the wet season (May-October); albeit they fluctuated as usual between the seasons [SATOMURA et al. 2010]. Both the GPSPWVs were compared with the PWV from the ERA-Interim reanalysis products at the Ubon Ratana reservoir (point A: $16.75^{\circ} \mathrm{N}, 102.5^{\circ} \mathrm{E}$ ) and the Lumpow reservoir (point B: $16.75^{\circ} \mathrm{N}$, $103.5^{\circ} \mathrm{E}$ ) (Fig. 1). We found that the ERAInterim PWV and the GPS-PWV trended similarly over the years (Fig. 3). A comparison of the average of daily PWV shows that they have a high coefficient of correlation (0.973) (Fig. 4); thus, GPS is an effective tool for PWV estimation.

\section{CORRELATIONS BETWEEN GPS-PWV AND THE INFLOW OF RESERVOIRS}

According to the records of the Royal Irrigation Department of Thailand, the Ubon Ratana reservoir has a maximum monthly inflow of $2,433 \cdot 10^{6} \mathrm{~m}^{3}$ and a minimum of
$5 \cdot 10^{6} \mathrm{~m}^{3}$ (average $277.96 \cdot 10^{6} \mathrm{~m}^{3}$ per month). Its highest daily inflow is $194 \cdot 10^{6} \mathrm{~m}^{3}$ and its lowest 0 (average $9.16 \cdot 10^{6} \mathrm{~m}^{3}$ per day). The Lumpow reservoir had the highest monthly inflow of $1,112 \cdot 10^{6} \mathrm{~m}^{3}$ while its lowest was 0 (average $147.92 \cdot 10^{6} \mathrm{~m}^{3}$ ), while its highest daily inflow was $101 \cdot 10^{6} \mathrm{~m}^{3}$ and its lowest was 0 (average $4.91 \cdot 10^{6} \mathrm{~m}^{3}$ per day). The inflow patterns revealed GPS-PWV fluctuations that appear as dwarf flows in the dry months and massive flows during the wet months.

The standardisations of monthly and daily GPSPWV for both reservoir inflows were compared (Figs. $5,6)$. The variation trended to unidirectional fluctuation, as the reservoir inflow peak shifted from the GPS-PWV peak over a few months (or 60-90 days). It is possible that the GPS-PWV is related to downpours, since the rainfall event often occurs when the GPS-PWV stays above $30 \mathrm{~mm}$ (Figs. 7, 8). The runoff will take time to reach the rivers; such that the intervening period is known as the time of concentration $\left(t_{c}\right)$, such that the GPS-PWV might indeed be related to reservoir inflow.

The respective relationship between monthly GPS-PWV and monthly inflow of both reservoirs indicates an upper-middle coefficient of correlation. Accordingly, the monthly inflow of the Ubon Ratana reservoir had its highest coefficients of correlation within the last $1-2$ months measured $(0.545$ and 0.523 ,

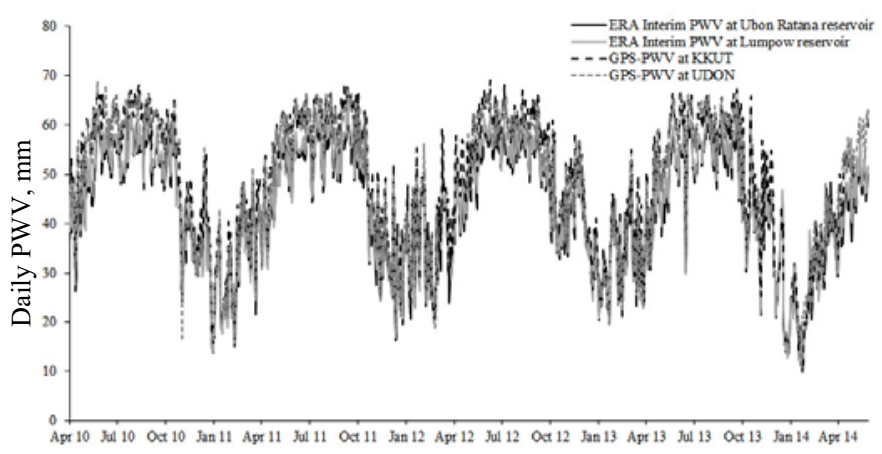

Fig. 3. Comparison of daily GPS-PWV and daily ERA-Interim PWV; $\mathrm{PWV}=$ precipitable water vapour, KKUT $=$ Khon Kaen station, UDON = Udon Thani station; source: own study

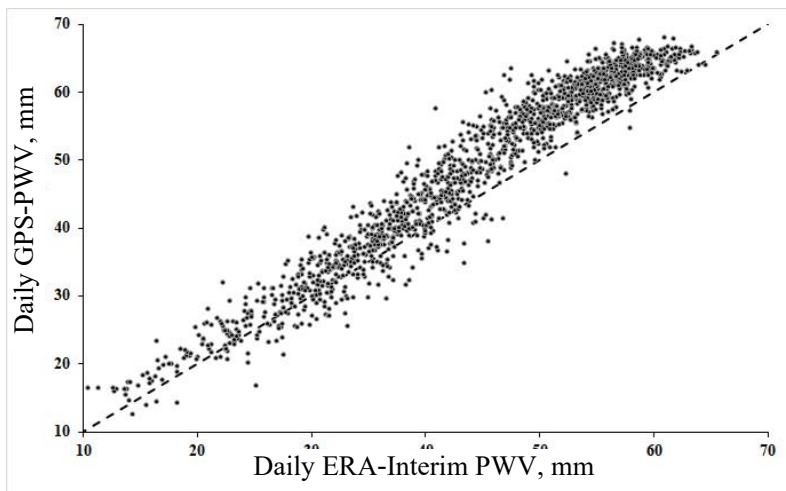

Fig. 4. Scatter plot of average daily GPS-PWV vs. average daily ERA-Interim PWV; PWV as in Fig. 3; source: own study 
a)

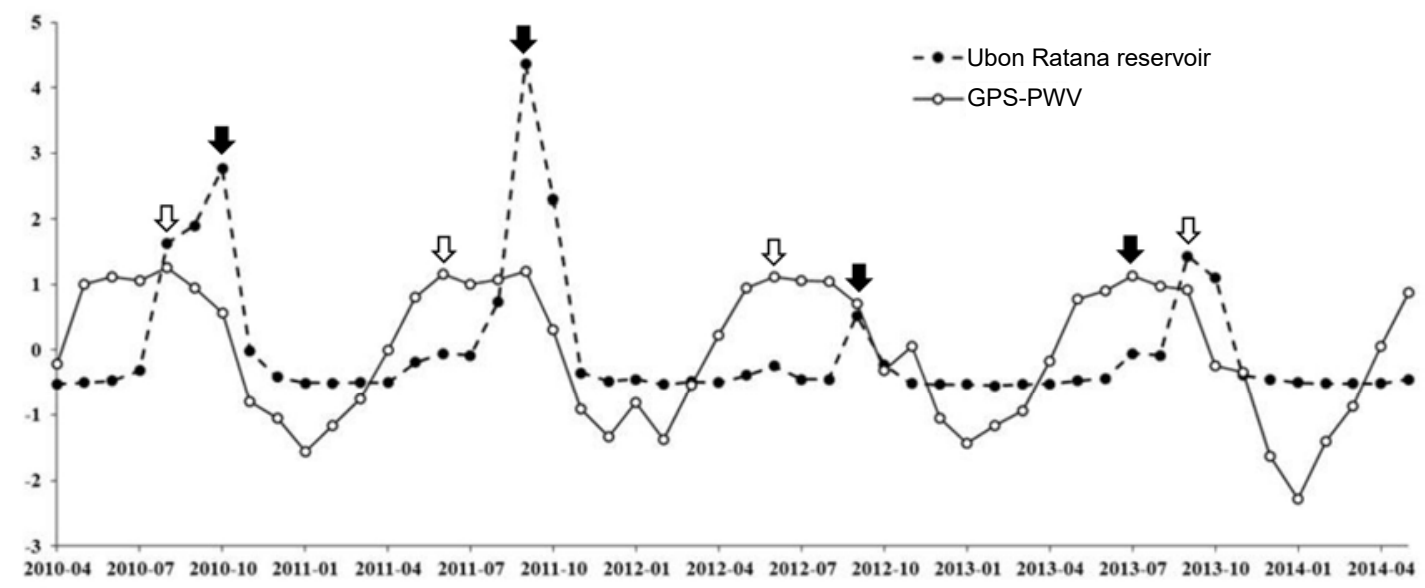

b)

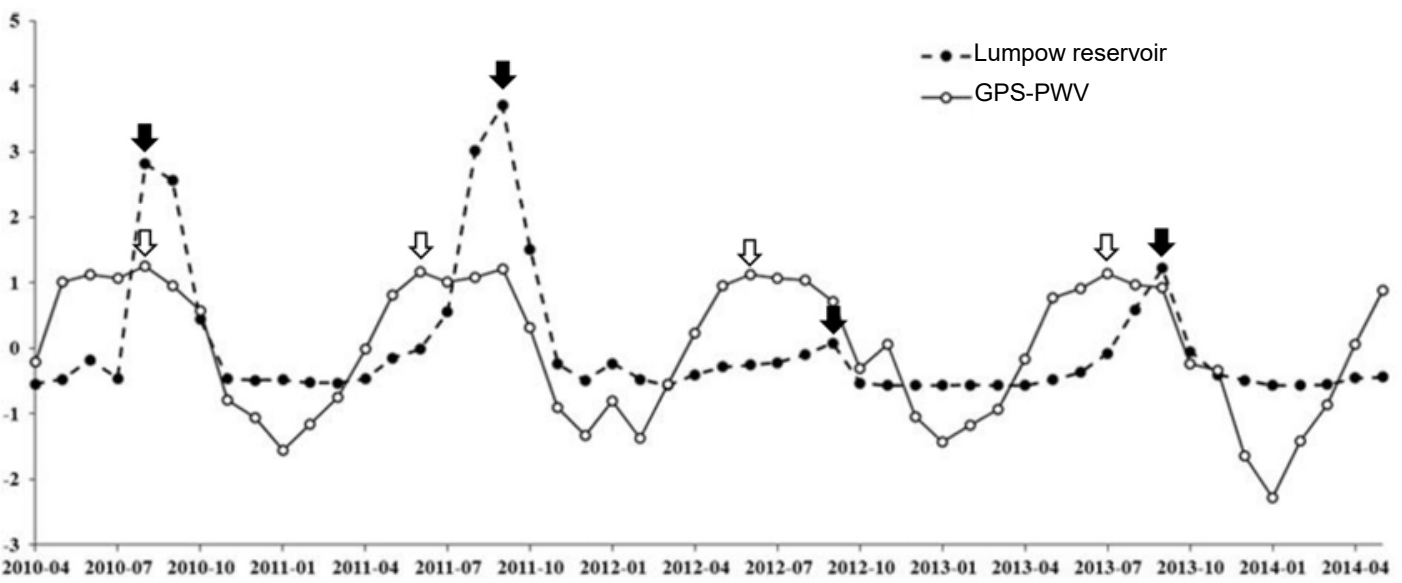

Fig. 5. Comparison of standardisations of monthly GPS-PWV and monthly inflows of: a) the Ubon Ratana reservoir,

b) the Lumpow reservoir (black arrow = peak of monthly inflow, white arrow = peak of monthly GPS-PWV); $\mathrm{PWV}=$ precipitable water vapour; source: own study

a) 12



b)

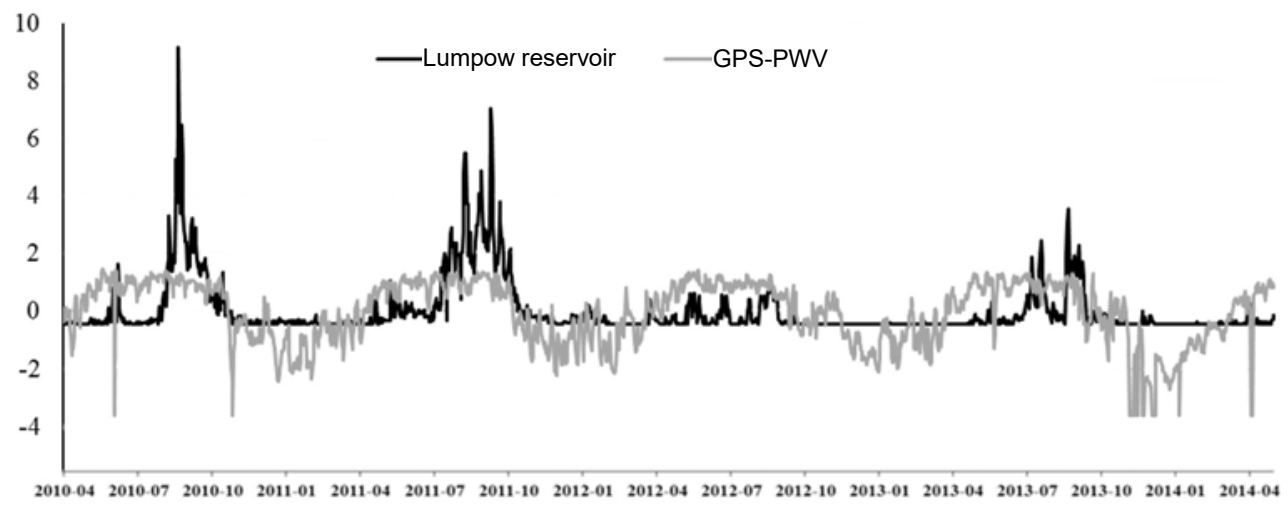

Fig. 6. Comparison of standardisations of daily GPS-PWV and daily inflows of: a) the Ubon Ratana reservoir, b) the Lumpow reservoir; PWV as Fig. 5; source: own study 

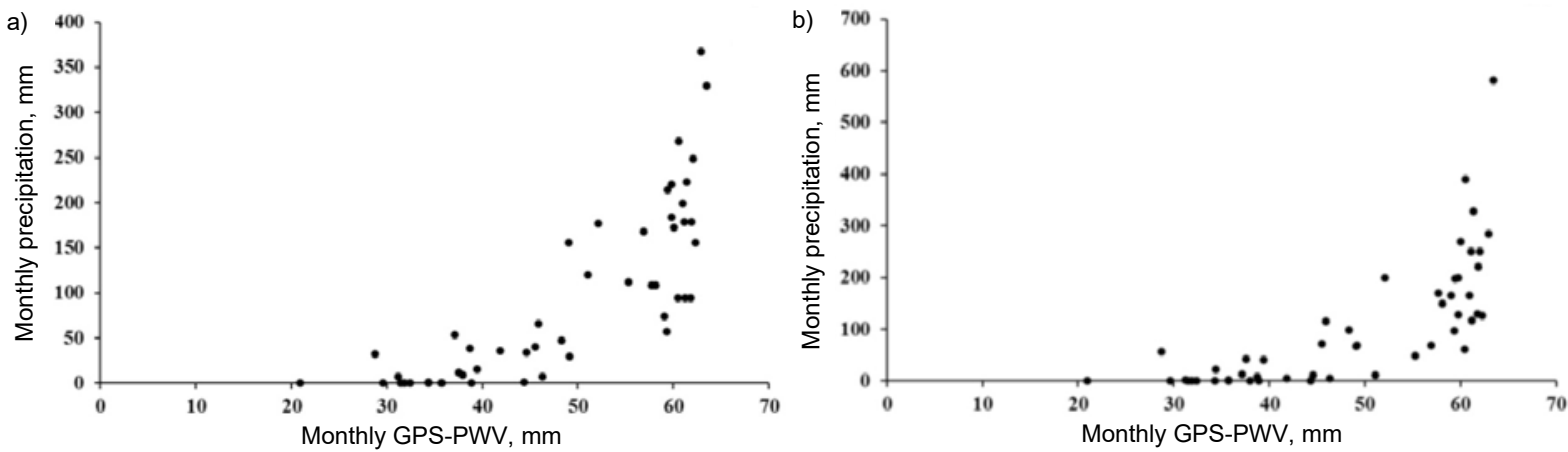

Fig. 7. Scatter plot of monthly precipitation vs. monthly GPS-PWV at: a) Khon Kaen station, b) Lumpow reservoir station; PWV as in Fig. 5; source: own study
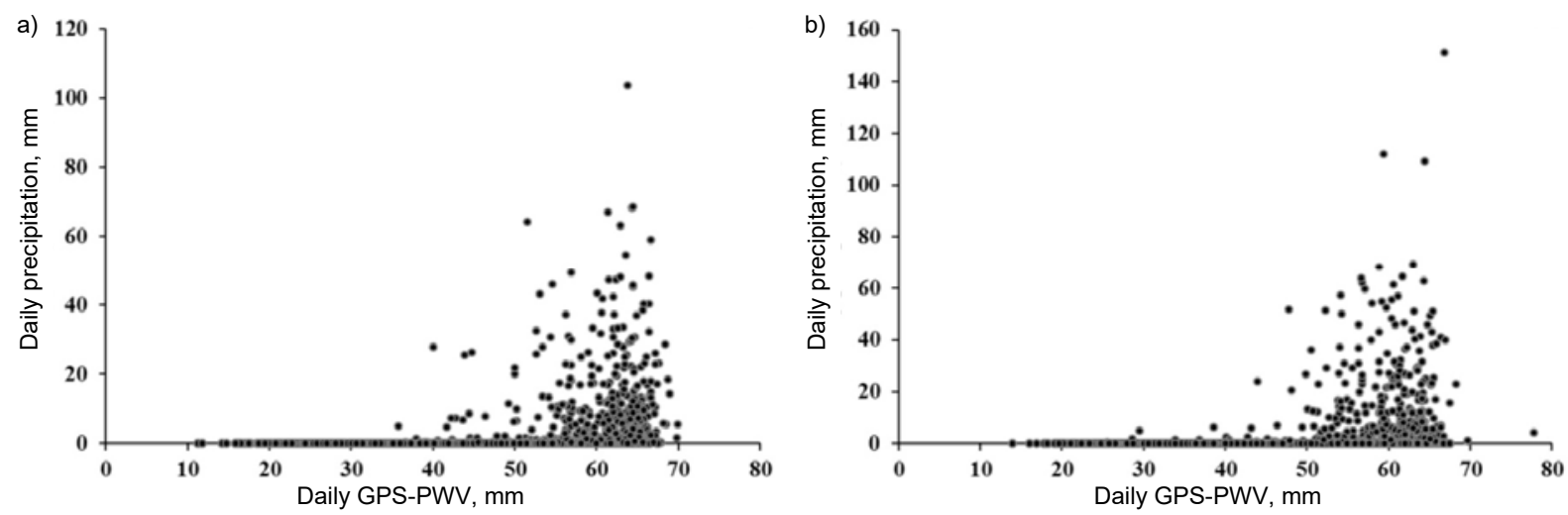

Fig. 8. Scatter plot of daily precipitation vs. daily GPS-PWV at: a) Khon Kaen station, b) Udon Thani station; PWV as in Fig. 5; source: own study
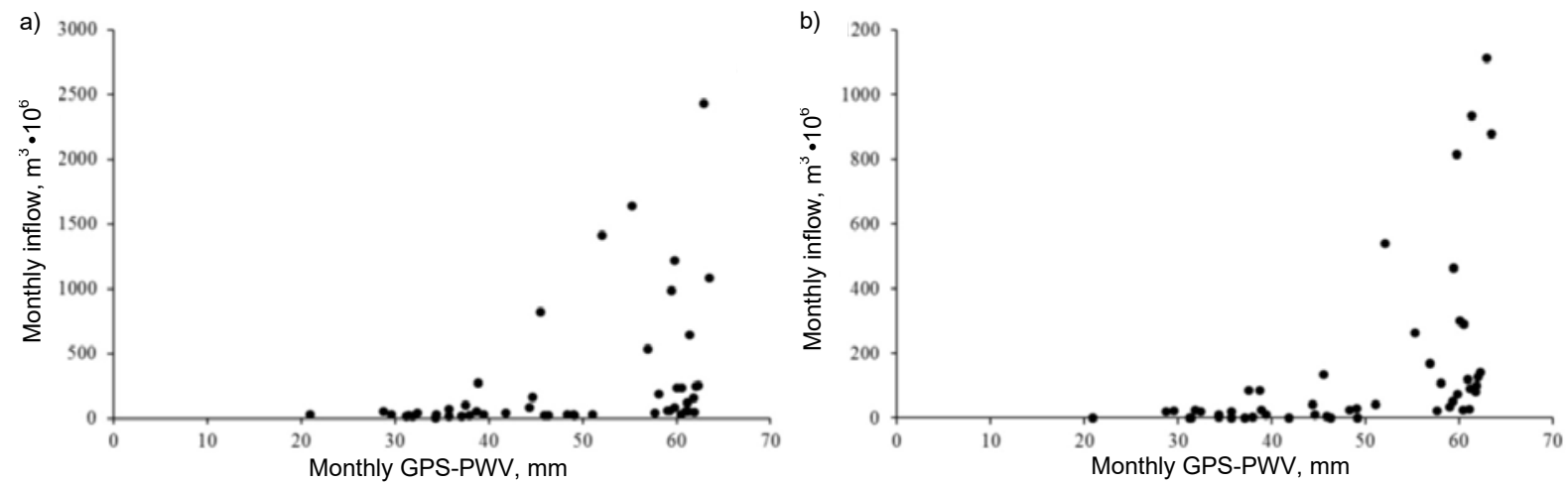

Fig. 9. Scatter plot of monthly inflow vs. monthly GPS-PWV at: a) Ubon Ratana reservoir, b) Lumpow reservoir; PWV as in Fig. 5; source: own study
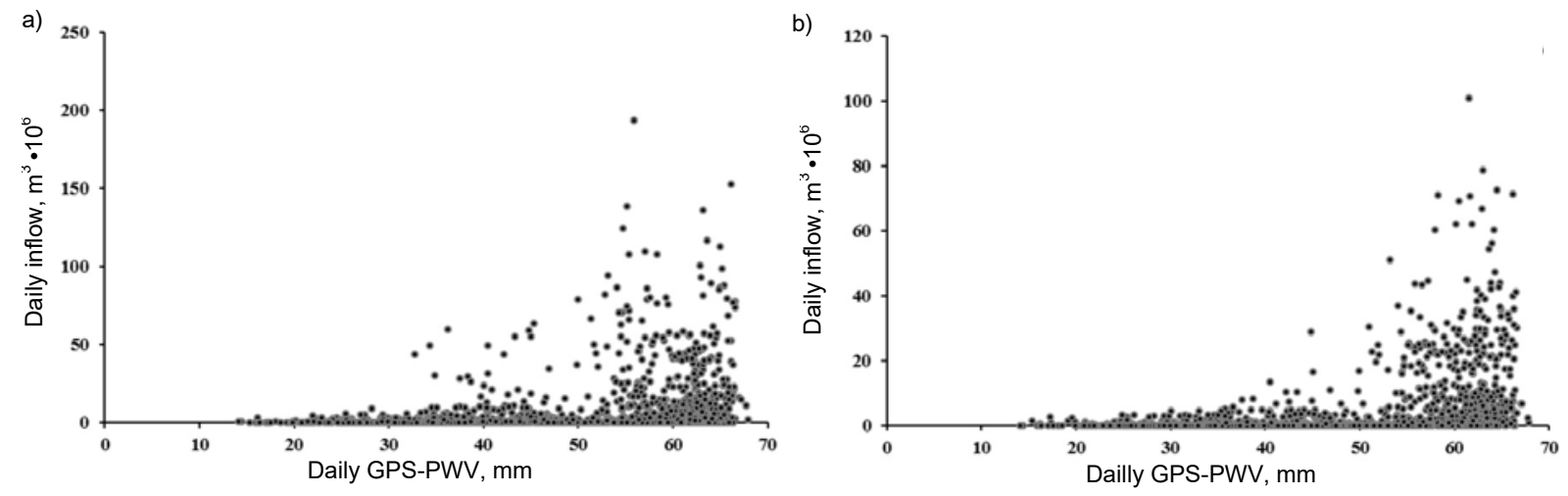

Fig. 10. Scatter plot of daily inflow vs. daily GPS-PWV at: a) Ubon Ratana reservoir, b) Udon Thani station; PWV as in Fig. 5; source: own study 
respectively). Similarly, the monthly inflow of the Lumpow reservoir had its highest coefficients of correlation within the last $1-2$ months measured $(0.566$ and 0.508 , respectively). The respective coefficient of correlation between daily GPS-PWV and daily inflow of each reservoir indicates a relationship less than the monthly data (i.e., the highest respective correlation coefficient for the Ubon Ratana and Lumpow reservoir was 0.420 and 0.440 ). The standardised comparisons reveal that the respective peak of reservoir inflow shifted away from the respective average GPS-PWV peak within a few months. The scatter plot of inflow versus GPS-PWV, moreover, showed that the high values for GPS-PWV often correlated with the extreme monthly inflow (Figs. 9, 10). Although the Pearson's correlation coefficient between inflow and GPS-PWV were intermediate, GMDH modelling a hidden relationship between them.

\section{POSSIBILITY TESTING OF GPS-PWV TO FORECAST RESERVOIR INFLOW USING GMDH}

Although the respective coefficient of correlation between the GPS-PWV and inflow is small, the GMDH can create an accurate model from the lowcorrelation variables. The retrospective monthly GPS-PWVs (i.e., the previous 1-5 months) were used as the input data for the monthly GMDH model; in order to predict the monthly reservoir inflow during the current month (Fig. 11a). The retrospective daily GPS-PWVs (i.e., the previous 1-90 days) was then used as the input data for the daily GMDH model, in order to predict the daily reservoir inflow during the then current day (Fig. 11b).

a)
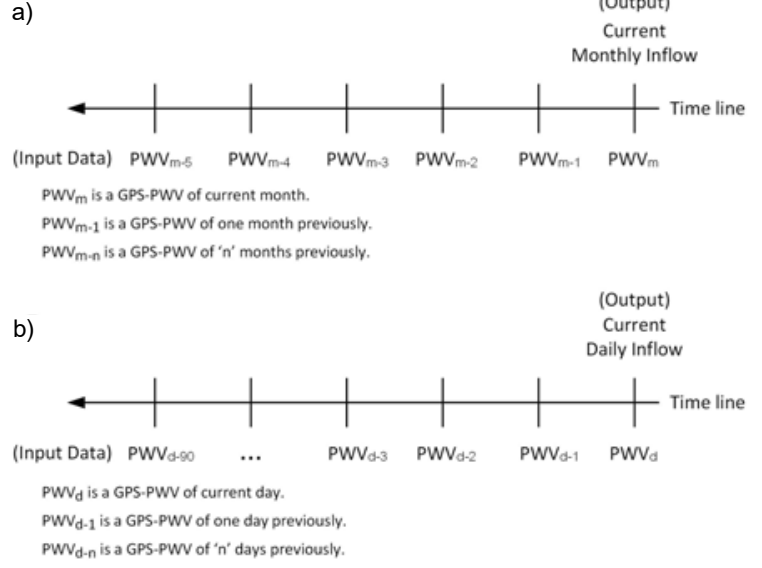

Fig. 11. Input-output structure of inflow model: a) monthly, b) daily; PWV as in Fig. 5; source: own study

The accuracy of the monthly Ubon Ratana model was hereby evaluated, and the mean absolute error $(M A E)$ of the model was $54.19 \cdot 10^{6} \mathrm{~m}^{3}$ per month, with a coefficient of determination $\left(R^{2}\right)$ of 0.97 and a coefficient of correlation of 0.99 . The validation of the model shows a $M A E$ of $61.36 \cdot 10^{6} \mathrm{~m}^{3}$ per month, with a $R^{2}$ of 0.93 , and a coefficient of correlation of
0.98 (Fig. 12a). The inflow prediction model for the monthly Lumpow reservoir model had a $M A E$ of $25.65 \cdot 10^{6} \mathrm{~m}^{3}$ per month, the best $R^{2}(0.98)$, and an equivalent coefficient of correlation of 0.99 . This validation was evaluated; wherein the $M A E$ was $46.64 \cdot 10^{6} \mathrm{~m}^{3}$ per month with a best $R^{2}$ of 0.72 and a coefficient of correlation of 0.93 (Fig. 12b).

The daily Ubon Ratana model was also evaluated, and the mean absolute error (MAE) of the model was $5.40 \cdot 10^{6} \mathrm{~m}^{3}$ per day, with a coefficient of determination $\left(R^{2}\right)$ of 0.78 and a coefficient of correlation of 0.89 . The validation of the model had a $M A E$ of $7.15 \cdot 10^{6} \mathrm{~m}^{3}$ per day, with an $R^{2}$ of 0.58 , and a coefficient of correlation of 0.77 (Fig. 13a). The inflow prediction model of the daily Lumpow reservoir model identification had a $M A E$ of $2.62 \cdot 10^{6} \mathrm{~m}^{3}$ per day, with the best $R^{2}(0.84)$, and an equivalent coefficient of correlation of 0.91 . This validation was evaluated; for which the $M A E$ was $3.71 \cdot 10^{6} \mathrm{~m}^{3}$ per month with the best $R^{2}$ of 0.61 and a coefficient of correlation of 0.79 (Fig. 13b).

Both the Ubon Ratana and Lumpow models present well-defined, validated models (Tab. 1). For this reason, rainfall which becomes an aspect of inflow to reservoir flow is directly linked to atmospheric humidity and temperature. As a result, GPS-PWVs represent water in the atmosphere column. Likewise, GPS-PWVs can be potential factors for use in hydrological monitoring (i.e., flood forecasts, drought assessment, and precipitation efficiencies) [BORDI et al. 2014; SUPARTA, RAHMAN, 2016], and the monthly and daily inflow forecasting model, which uses GPS-PWV as input data which responds excellently to extreme inflow (Figs. 14, 15). An advantage of GPS-PWV is that it is not included in other parameters. For the validation of all models, it is plausible that GPS-PWV probabilities contribute significantly to receiving information about runoff in any given area. It is highly likely that GPS-PWV forecasts can be used to predict the inflows of reservoirs.

Table 1. Accuracy comparison between monthly and daily models

\begin{tabular}{|l|c|c|c|c|c|}
\hline \multirow{2}{*}{ Model } & \multirow{2}{*}{\begin{tabular}{c} 
Average \\
inflow \\
\cline { 3 - 6 }
\end{tabular}} & \multicolumn{2}{c|}{$\begin{array}{c}\text { Model } \\
\text { identification }\end{array}$} & \multicolumn{2}{c|}{ Validation } \\
\cline { 2 - 6 } & & $R^{2}$ & $\begin{array}{c}\text { MAE } \\
10^{6} \mathrm{~m}^{3}\end{array}$ & $R^{2}$ & $\begin{array}{c}\text { MAE } \\
10^{6} \mathrm{~m}^{3}\end{array}$ \\
\hline Ubon Ratana model \\
\hline Monthly model & 277.96 & 0.97 & 54.19 & 0.93 & 61.36 \\
\hline Daily model & 9.16 & 0.78 & 5.40 & 0.58 & 7.15 \\
\hline \multicolumn{7}{|c|}{ Lumpow reservoir model } \\
\hline Monthly model & 147.92 & 0.98 & 25.65 & 0.72 & 46.64 \\
\hline Daily model & 4.91 & 0.84 & 2.62 & 0.61 & 3.71 \\
\hline
\end{tabular}

Explanations: $R^{2}=$ coefficient of determination; $M A E=$ mean absolute error.

Source: own study.

Since all other factors that might cause shifts have been accounted for, GPS-PWV should remain a tool for weather forecasting and hydrological monitoring, and also be used to improve rainfall models for many 

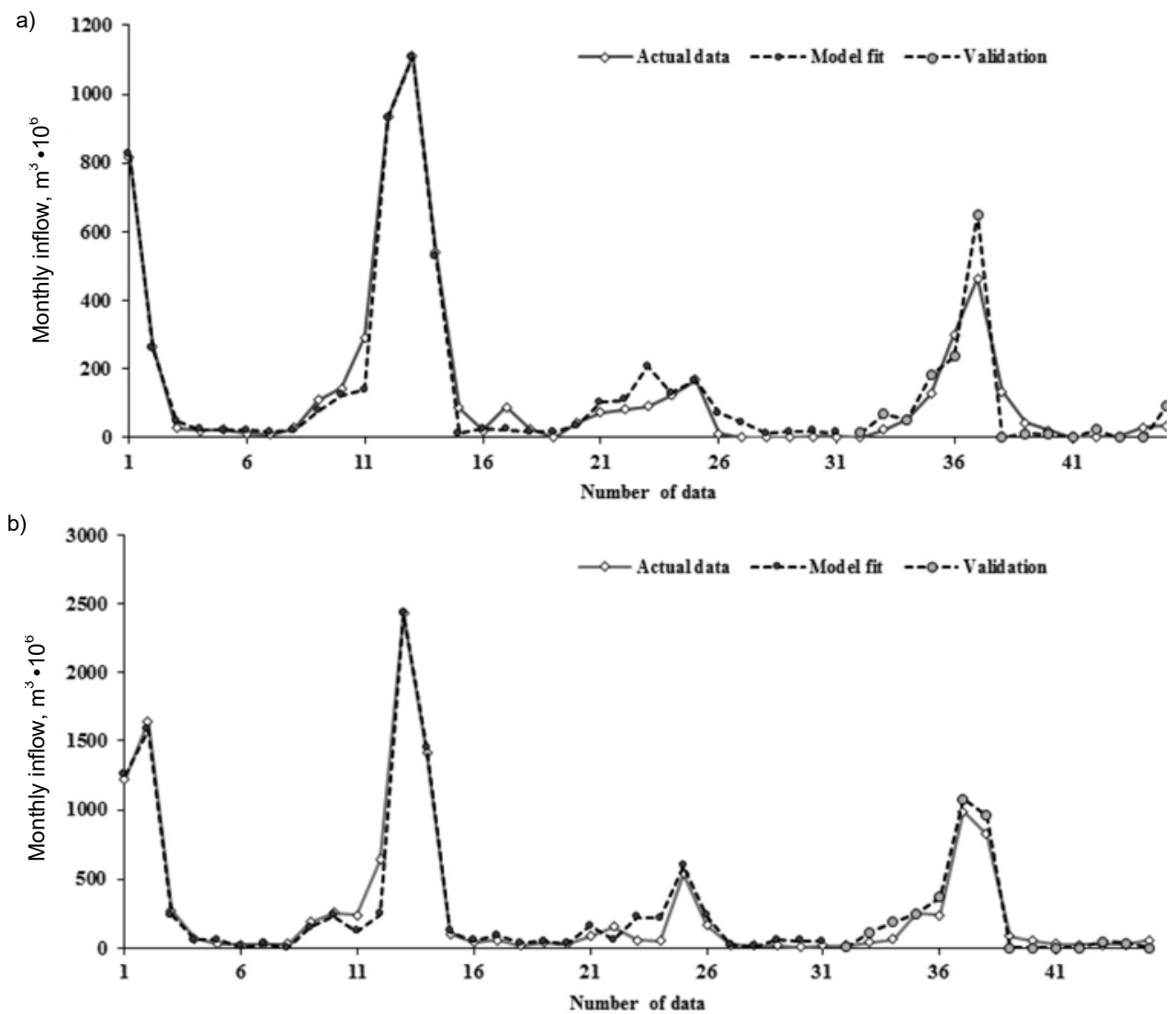

Fig. 12. Monthly model fitting and validation of forecasted models: a) Ubon Ratana, b) Lumpow; source: own study
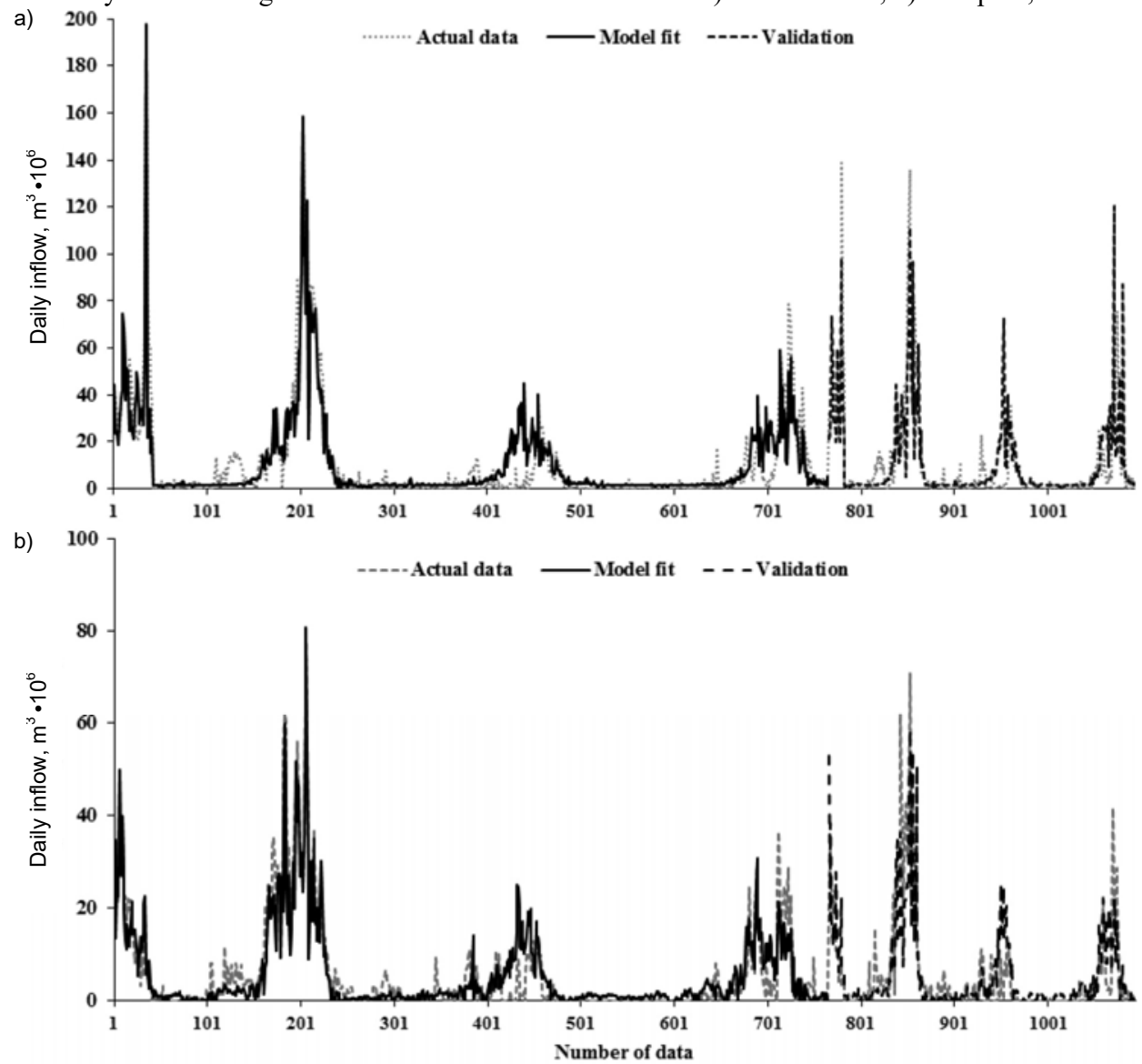

Fig. 13. Daily model fitting and validation of forecasted models: a) Ubon Ratana, b) Lumpow; source: own study 

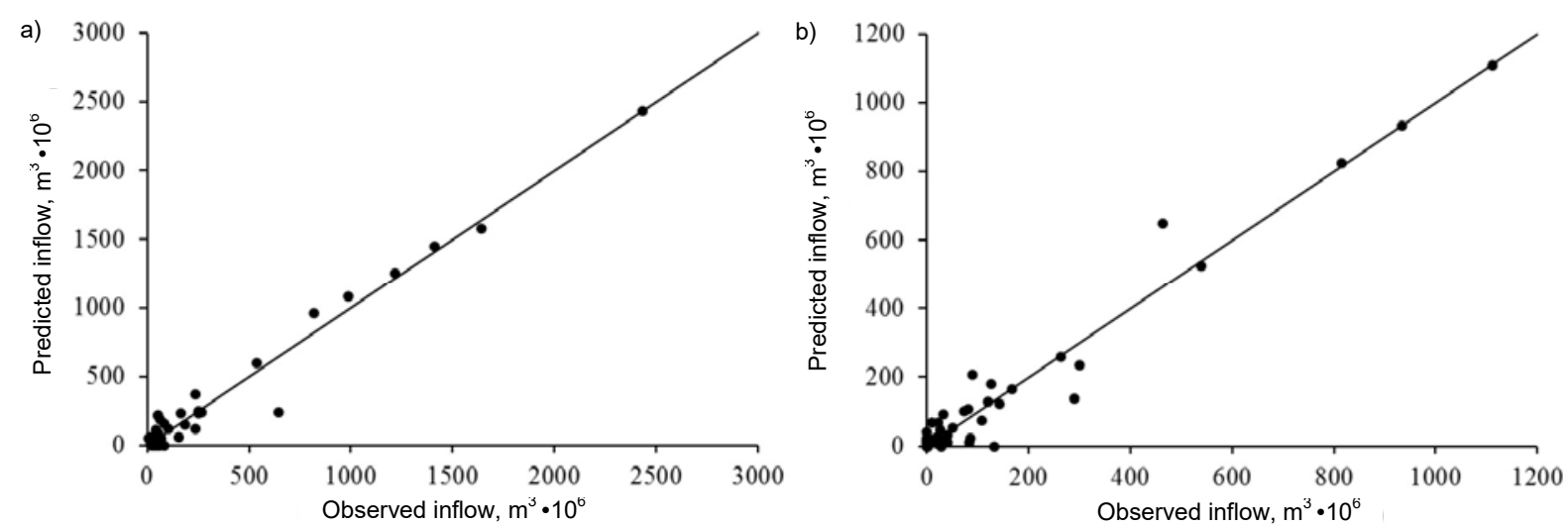

Fig. 14. Observed monthly inflow vs. predicted monthly inflow: a) Ubon Ratana model, b) Lumpow model; source: own study
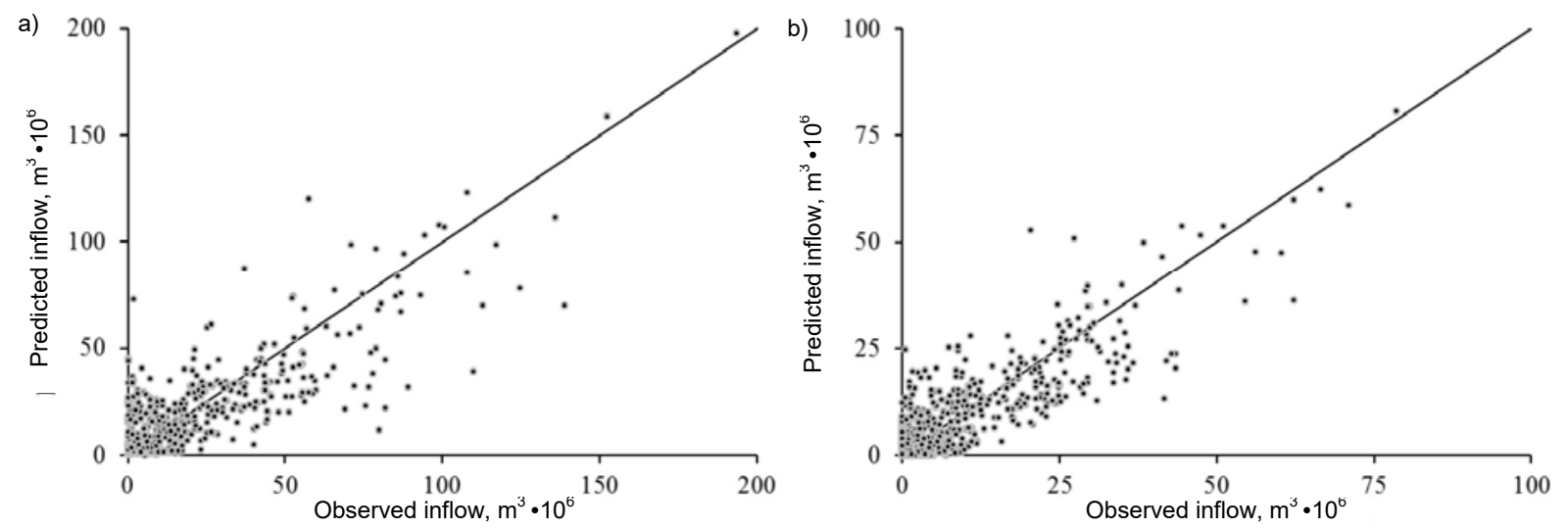

Fig. 15. Observed daily inflow vs. predicted daily inflow: a) Ubon Ratana model, b) Lumpow model; source: own study

of the numerical weather prediction models (i.e., short-range numerical model systems incorporating three-dimensional variations (SSNS-3DVARs) [LEIMING et al. 2012], which rely upon the same measurements as are used in hydrological studies [BORDI et al. 2014]. The Ubon Ratana and Lumpow models used GPS-PWVs as the core variable for predicting inflows, which had a high degree of reliability. It is possible that reservoir inflows can thus be used to forecast inflow volumes using GPS-PWV, or to shadow rainfall itself.

\section{CONCLUSIONS}

The daily and monthly inflows of reservoirs trend to vary between monthly GPS-PWV assessments. The standardisation of the two reservoirs used in the current study revealed that such inflows vary in direct proportion to GPS-PWV assessments; wherein the assessed peaks trend towards similar patterns of inflows some of the time. Correlation analysis revealed that the highest coefficients of correlation between monthly inflow and GPS-PWV were within 1-2 months of the GPS-PWV observations. The respective coefficient of correlation between daily inflow and GPS-PWV was lower than the monthly correlation. The GPS-PWV can be used for the atmospheric hu- midity connected to rainfall, which takes time to concentrate before run-off arises. Models received from the respective identification processes, as with the present study, require more in-depth investigations to know how they will perform. The models had high $R^{2}$ values, high coefficients of correlation, and acceptable $M A E \mathrm{~s}$, confirming a strong relationship between both. The validation of both models produced effective and satisfactory results; moreover, the models which used GPS-PWV as input data responded to extreme inflow better than traditional variables. The monthly models have higher accuracy than the daily model, since the nature of GPS-PWV slowly varies followed by daily inflow. The monthly GPS-PWVs, which have a longer duration, are more compatible with monthly inflow. Accordingly, the GPS-PWV has potential for reservoir inflow forecasting.

\section{Acknowledgments}

The authors thank (a) the Research Fund of the Faculty of Engineering, at Khon Kaen University, for supporting this project, (b) the Department of Public Works and Town \& Country Planning of Thailand for providing the RINEX files of Udon Thani, (c) the Royal Irrigation Department of Thailand for providing the reservoir inflows, and (d) Mr. Bryan Roderick Hamman for assistance with the Englishlanguage presentation of the manuscript. 


\section{REFERENCES}

AbDEllatiF M.E., Osman Y.Z., Elkhidir A.M. 2015. Comparison of artificial neural networks and autoregressive model for inflows forecasting of Roseires Reservoir for better prediction of irrigation water supply in Sudan. International Journal of River Basin Management. Vol. 13 p. 203-214.

AKilan A., AZEez K.K.A., Balaji S., Schuh H., SRINIVAS Y. 2015. GPS derived Zenith Total Delay (ZTD) observed at tropical locations in South India during atmospheric storms and depressions. Journal of Atmospheric and Solar-Terrestrial Physics. Vol. 125-126 p. 1-7.

ASKNE J., NORDIUS H. 1987. Estimation of tropospheric delay for microwaves from surface weather data. Radio Science. Vol. 22 p. 379-386.

BAi Y., Chen Z., XIE J., Li C. 2016. Daily reservoir inflow forecasting using multiscale deep feature learning with hybrid models. Journal of Hydrology. Vol. 532 p. 193206.

BAiley R.T., Wible T.C., ARABi M., Records R.M., DitTy J. 2016. Assessing regional-scale spatio-temporal patterns of groundwater-surface water interactions using a coupled SWAT-MODFLOW model. Hydrological Processes. Vol. 30. Iss. 23 p. 4420-4433.

Bevis M., Businger S., Chiswell S., Herring T.A., ANTHES R.A., Rocken C., WARE R.H. 1994. GPS Meteorology: Mapping zenith wet delays onto precipitable water. Journal of Applied Meteorology. Vol. 33 p. 379386.

Bordi I., Raziei T., Pereira L.S., Sutera A. 2014. GroundBased GPS measurements of precipitable water vapor and their usefulness for hydrological applications. Water Resources Management. Vol. 29. Iss. 2 p. 471-486.

Bordi I., ZhU X., Fraedrich K. 2016. Precipitable water vapor and its relationship with the Standardized Precipitation Index: ground-based GPS measurements and reanalysis data. Theoretical and Applied Climatology. Vol. 123 p. $263-275$.

CHEN B., LiU Z. 2014. Analysis of precipitable water vapor (PWV) data derived from multiple techniques: GPS, WVR, radiosonde and NHM in Hong Kong. Lecture Notes in Electrical Engineering. Vol. 303 p. 159-175.

Choy S., Wang C.-S., Yeh T.-K., Dawson J., Jia M., KuleSHOV Y. 2015. Precipitable water vapor estimates in the Australian Region from ground-based GPS Observations. Advances in Meteorology. Vol. 2015 p. 1-14.

Collischonn W., TuCCI C.E.M., Clarke R.T., Chou S.C., Guilhon L.G., Cataldi M., Allasia D. 2007. Medium-range reservoir inflow predictions based on quantitative precipitation forecasts. Journal of Hydrology. Vol. 344 p. 112-122.

Coulibaly P., Anctil F., Bobée B. 2000. Daily reservoir inflow forecasting using artificial neural networks with stopped training approach. Journal of Hydrology. Vol. 230 p. 244-257.

CUI Q., WANG X., Li C., CAI Y., Liang P. 2016. Improved Thomas-Fiering and wavelet neural network models for cumulative errors reduction in reservoir inflow forecast. Journal of Hydro-environment Research. Vol. 13 p. $134-143$.

Davis J.L., Herring T.A., Shapiro I.I., Rogers A.E.E., ELGERED G. 1985. Geodesy by radio interferometry: Effects of atmospheric modeling errors on estimates of baseline length. Radio Science. Vol. 20 p. 1593-1607.
DEETER M.N. 2007. A new satellite retrieval method for precipitable water vapor over land and ocean. Geophysical Research Letters. Vol. 34. Iss. 2 pp. 5.

DHI 2004. MIKE 11 User \& reference manual. Hørsholm. Danish Hydraulic Institute pp. 510.

EBTEHAJ I., BonAKDARI H., ZaJI A.H., AZIMI H., KHOSHBIN F. 2015. GMDH-type neural network approach for modeling the discharge coefficient of rectangular sharpcrested side weirs. Engineering Science and Technology, an International Journal. Vol. 18. Is. 4 p. 746-757.

ElgEREd G., DAVIS J.L., Herring T.A., ShaPIRo I.I. 1991. Geodesy by radio interferometry: Water vapor radiometry for estimation of the wet delay. Journal of Geophysical Research: Solid Earth. Vol. 96 p. 6541-6555.

Herring T.A., King R.W., Floyd M.A., McClusky S.C. 2015. GAMIT Reference Manual GPS Analysis at MIT Release 10.6. Massachusetts. Massachusetts Institute of Technology pp. 167.

IVAKHNENKO A.G. 1971. Polynomial theory of complex systems. IEEE Transactions on Systems, Man and Cybernetics SMC-1 p. 364-378.

Ji D., Shi J., Xiong C., Wang T., Zhang Y. 2017. A total precipitable water retrieval method over land using the combination of passive microwave and optical remote sensing. Remote Sensing of Environment. Vol. 191 p. 313-327.

JoTHIPRAKASH V., KoTE A.S. 2011. Improving the performance of data-driven techniques through data preprocessing for modelling daily reservoir inflow. Hydrological Sciences Journal. Vol. 56 p. 168-186.

Kuleshov Y., Choy S., Fu E.F., Chane-Ming F., Liou Y.-A., PAVELYeV A.G. 2016. Analysis of meteorological variables in the Australasian region using ground- and space-based GPS techniques. Atmospheric Research. Vol. $176-177$ p. 276-289.

Leiming M., Fuhai G., Qigige W., GuAngGiang Z. 2012. Numerical weather prediction in Yangtze River Delta region with assimilation of AWS and GPS/PWV data. In: 2012 IEEE Symposium on Robotics and Applications (ISRA). Proceedings. 3-5.06.2012 Kuala Lumpur, Malaysia. Kuala Lumpur. IEE p. 741-743.

Liang H., CaO Y., WAN X., Xu Z., WANG H., Hu H. 2015. Meteorological applications of precipitable water vapor measurements retrieved by the national GNSS network of China. Geodesy and Geodynamics. Vol. 6 p. 135142.

Lima L.M.M., Popova E., Damien P. 2014. Modeling and forecasting of Brazilian reservoir inflows via dynamic linear models. International Journal of Forecasting. Vol. 30 p. $464-476$.

Llamedo P., Hierro R., De la Torre A., Alexander P. 2017. ENSO-related moisture and temperature anomalies over South America derived from GPS radio occultation profiles: ENSO-related anomalies over South America. International Journal of Climatology. Vol. 37 p. $268-275$.

MAGAR R.B., JOTHIPRAKASH V. 2011. Intermittent reservoir daily-inflow prediction using lumped and distributed data multi-linear regression models. Journal of Earth System Science. Vol. 120 p. 1067-1084.

Maghrabi A., Al Dajani H.M. 2013. Estimation of precipitable water vapour using vapour pressure and air temperature in an arid region in central Saudi Arabia. Journal of the Association of Arab Universities for Basic and Applied Sciences. Vol. 14 p. 1-8.

Namaoui H., Kahlouche S., Belbachir A.H., Van Malderen R., Brenot H., Pottiaux E. 2017. GPS wa- 
ter vapor and its comparison with radiosonde and ERAInterim data in Algeria. Advances in Atmospheric Sciences. Vol. 34 p. 623-634.

NAyAK P.C., VenKatesh B., Krishna B., Jain S.K. 2013. Rainfall-runoff modeling using conceptual, data driven, and wavelet based computing approach. Journal of Hydrology. Vol. 493 p. 57-67.

NoOr H., Vafakhah M., Taheriyoun M., Moghadasi M. 2014. Hydrology modelling in Taleghan mountainous watershed using SWAT. Journal of Water and Land Development. No. 20 p. 11-18.

Patro S., Chatterjee C., Mohanty S., Singh R., RaghuWANSHI N.S. 2009. Flood inundation modeling using MIKE FLOOD and remote sensing data. Journal of the Indian Society of Remote Sensing. Vol. 37 p. 107-118.

Satomura M., Shimonaka E., UKei K., Shimada S., Kato T., Wu P., Hashimoto M., Kingpaiboon S., Thana B. 2010 . On the precipitable water vapor obtained by using GPS observations in Thailand (2001-2006). Geoscience Reports of the Shizuoka University p. 1-11.

SOHN D.-H., PARK K.-D., WON J.-H., CHO J.-H., ROH K.-M. 2012. Comparison of the characteristics of precipitable water vapor measured by Global Positioning System and microwave radiometer. Journal of Astronomy and Space Sciences. Vol. 29 p. 1-10.

Suparta W., Adnan J., Ali M.A.M. 2012. Monitoring of GPS precipitable water vapor during the severe flood in Kelantan. American Journal of Applied Sciences. Vol. 9 p. 825-831.

SUPARTA W., ISKANDAR A. 2012. Monitoring of GPS water vapor variability during ENSO events over the Borneo Region. Asian Journal of Earth Sciences. Vol. 5 p. 88-95.

SUPARTA W., RAHMAN R. 2016. Spatial interpolation of GPS PWV and meteorological variables over the west coast of Peninsular Malaysia during 2013 Klang Valley flash flood. Atmospheric Research. Vol. 168 p. 205-219.

Taghi Sattari M., YureKli K., PAL M. 2012. Performance evaluation of artificial neural network approaches in forecasting reservoir inflow. Applied Mathematical Modelling. Vol. 36 p. 2649-2657.

Tsuda T., Sato K., Realini E., Oigawa M., Iwaki Y., Shoji Y., SEKO H. 2013. A real-time monitoring system of precipitable water vapor (PWV) using a dense GNSS receiver network. Journal of Disaster Research. Vol. 8 p. $155-156$.

Uang-AReE P., KingPaiboon S., Khuanmar K. 2014. Estimation of missing GPS precipitable water vapor data by zenith wet delay and meteorological data. Advanced Materials Research. Vol. 931-932 p. 703-708.

Uang-ARee P., KingPaiboon S., Khuanmar K. 2015. Determination of the dates of the southwest monsoon in northeastern Thailand from the data on precipitable water vapor obtained by GPS. Russian Meteorology and Hydrology. Vol. 40 p. 647-657.

VAlipour M., BANihabib M.E., Behbahani S.M.R. 2012. Monthly inflow forecasting using autoregressive artificial neural network. Journal of Applied Sciences. Vol. 12 p. 2139-2147.

VAlipour M., Banihabib M.E., Behbahani S.M.R. 2013. Comparison of the ARMA, ARIMA, and the autoregressive artificial neural network models in forecasting the monthly inflow of Dez dam reservoir. Journal of Hydrology. Vol. 476 p. 433-441.

Wang W., Chau K., Xu D., Chen X.-Y. 2015. Improving forecasting accuracy of annual runoff time series using ARIMA based on EEMD Decomposition. Water Resources Management. Vol. 29 p. 2655-2675.

YeH T.-K., Hong J.-S., WANG C.-S., ChEN C.-H., ChEN K.-H., FonG C.-T. 2016. Determining the precipitable water vapor with ground-based GPS and comparing its yearly variation to rainfall over Taiwan. Advances in Space Research. Vol. 57 p. 2496-2507.

Zealand C.M., BuRn D.H., Simonovic S.P. 1999. Short term streamflow forecasting using artificial neural networks. Journal of Hydrology. Vol. 214 p. 32-48.

\section{Prawit UANG-AREE, Sununtha KINGPAIBOON}

\section{Możliwość prognozowania dopływu do zbiornika na podstawie danych GPS o zawartości pary wodnej}

\section{STRESZCZENIE}

W pracy przedstawiono wyniki badań możliwości użycia danych GPS o zawartości pary wodnej (GPS-PWV) do prognozowania dopływu do zbiornika. Analizowano korelacje między miesięczną wartością GPS-PWV a dopływem do dwóch zbiorników; zależność testowano, stosując algorytm sieci neuronowej, zwany metodą grupowania argumentów (GMDH). Dobowe i miesięczne dopływy do zbiorników były proporcjonalne do dobowych i miesięcznych trendów GPS-PWV. Maksymalny dopływ odbiegał jednak od maksymalnych średnich GPS-PWV. Silna zależność między GPS-PWV a dopływem została potwierdzona dużymi wartościami $R^{2}$, wysokim współczynnikiem korelacji i akceptowalnym średnim błędem bezwzględnym (MAE) zarówno w modelu dobowym, jak i miesięcznym. W modelu dla zbiornika Ubon Ratana miesięczny błąd bezwzględny wynosił $54,19 \cdot 10^{6} \mathrm{~m}^{3}$ a dobowy $-5,40 \cdot 10^{6} \mathrm{~m}^{3}$. Dla porównania w modelu dla zbiornika Lumpow wartość miesięczna $M A E$ wynosiła $25,65 \cdot 10^{6} \mathrm{~m}^{3}$, a dobowa $2,62 \cdot 10^{6} \mathrm{~m}^{3}$. Modele $\mathrm{z}$ wykorzystaniem GPS-PWV jako danych wejściowych reagowały lepiej niż tradycyjne zmienne na dopływ ekstremalny i dlatego dopływ do zbiornika można przewidzieć bez znajomości rzeczywistego dopływu i danych opadowych. GPS-PWV jest więc pomocnym narzędziem w regionalnej i narodowej gospodarce wodnej. Potrzebne są dalsze badania obejmujące większą liczbę zbiorników, aby potwierdzić prezentowane wyniki wstępne.

Słowa kluczowe: $G M D H$, gospodarka wodna, hydrologia, PWV, zlewnia 